\title{
DISTRIBUTION STUDIES ON WILD MUSHROOM SPECIES FROM DISTRICT POONCH, AZAD JAMMU AND KASHMIR
}

\author{
Muhammad Tahir Younas, Syed Riaz Ali Gardezi, Muhammad Tariq-Khan \\ Department of Plant Pathology, Faculty of Agriculture, The University of Poonch, Rawalakot, Azad Jammu and Kashmir, \\ Pakistan.
}

\section{A R T I C L E I N F O}

\section{Article history \\ Received: $16^{\text {th }}$ January, 2018 \\ Revised: $18^{\text {th }}$ February, 2018 \\ Accepted: 20th February, 2018}

\section{Keywords \\ Mushroom \\ Poonch, Kashmir \\ flora}

\begin{abstract}
Present study was carried out in the Poonch District Azad Jammu and Kashmir targeting mushroom special flora found in their natural habitat around the year. Mushrooms were collected, preserved and identified during survey. Mushrooms Pilus lamella, stipe values were measured. The major identified species were Agaricus arvensi, Amanita vaginata, A. fulva, Cantharellus cinereus, Coprinus micaceus, C. comatus, C. domesticus, Cycoperdon perlatum, Daedalea quercina, Helvella crispa, Hygrophuorus melizeus, Lepista nuda, Lactarius turpis, Marasmius alliaceus, Panaeolus campanulatus, Pleurotus ostreatus, Trametes versicolor, and Tricholoma ustaloides. This study reveals mushroom flora and species diversity as important component of the natural environment in District Poonch Azad Jammu and Kashmir.
\end{abstract}

Corresponding Author: Muhammad Tariq-Khan

Email: muhammadtariq@upr.edu.pk

(C) 2018 EScience Press. All rights reserved.

\section{INTRODUCTION}

Mushrooms as a group are found all over the world. Mushrooms are most relished food commodities among the number of non-conventional foodstuffs primarily because of their unique flavor and texture (Courtenay and Burdsall, 1982; Kibby, 1979). Wild edible mushrooms have been collected and consumed by people since thousands of years. Archaeological evidences reveal edible species associated with people living 13000 years ago in Chile (Rojas and Mansur, 1995). But it is in China where the eating of wild fungi was first reliably noted several hundred years before birth of the Christ (Boa, 2004). Many cultures, especially in the Orient, identified that certain mushrooms could have profound health promoting benefits (Hobbs, 1995). Mushrooms have been exploited commercially world over and may be cultivated or gathered from the wild (Boa, 2004). The rate of consumption of fleshy fungi in many countries has increased in recent years and hence it becomes imperative to explore the treasure of wild mushroom (Pandey and Singh, 1978).

Mushrooms are cosmopolitan heterotrophic organisms that are quite specific in their nutritional and ecological requirements. They have been generally divided into humicolous, lignicolous, coprophilous, fungicolous, parasitic or saprophytic or may show some mycorrhizal associations with both broad-leaved forest trees and gymnosperms (Gardezi, 2005). The individual organism (the "body" of the fungus) consists of an extensive network of very finely branched microscopic threads called hyphae. Collectively, the hyphae making up such a network are referred to as a mycelium. The structure we recognize as a mushroom is in reality just a highly organized system of hyphae specialized for reproduction 
that develops from the otherwise vegetative mycelium inhabiting soil, leaf litter, or decaying wood. The individual hyphae obtain the nutrients and water, the fungus needs to grow. After a period of growth and under favorable conditions of temperature and moisture, the mycelium gives rise to one or more fruiting bodies called as mushrooms.

Long-distance dispersal is achieved by the many millions of microscopic spores produced by the fruiting body. These spores can be carried by wind currents to very distant places. A few of the mushrooms seen in one place may have arrived from another part of the world as mushroom spores borne on wind currents. Others may have arrived in a very different way, perhaps on soil adhering to plants, shipping containers, or boots, or even within the bodies of plants carried from one country to another by early settlers. As a result, it can be very difficult to distinguish between a country's native fungi and those that have been introduced or have recently arrived from elsewhere (Hall et al., 2003). Mushrooms are found everywhere, in front yards, on shade trees, in parks, fields and forests. Many species of mushrooms are formed slowly just beneath the surface of the soil, developing over a period of weeks or even months. When they are almost completely formed and if there is enough moisture present, the stipe elongates rather suddenly and raises the cap up into the air, the cap expanding as it is raised. These soft and delicate mushrooms can exert a surprising force when expanding in this way; they sometimes rise up rocks of several pounds' weight and have been known to force paving blocks up out of the street (Christensen, 1970). In late autumn, late winter and early spring are very good time to see many of the mushrooms. The natural Oak forest especially under or at the base of oak trees are actually the best places to see common edible and rare mushrooms. However, in the grassland and at the edge of streams and rivers the best are seen on the old dead wood and veteran trees Læssøe and Lincoff (1999) Fomes and Tramets mushroom found mainly living on old dead trunks in forests. Maximum protein value $32.59 \%$ in Helvella lacunose existing in mushroom fauna has been reported (Gardezi, 2000). The objective of this study was identification of wild mushroom and their distribution in their natural habitat during summer season in District Poonch of Azad Kashmir, Pakistan.

\section{MATERIALS AND METHODS}

Survey: Various locations of District Poonch were visited for presence and occurrence of the mushrooms during the period from February-2015 to May-2016. Major visited areas were Abbaspur, Banjoosa, Chotagala, Hajira, Khaigala and Rawalakot (Figure 1).

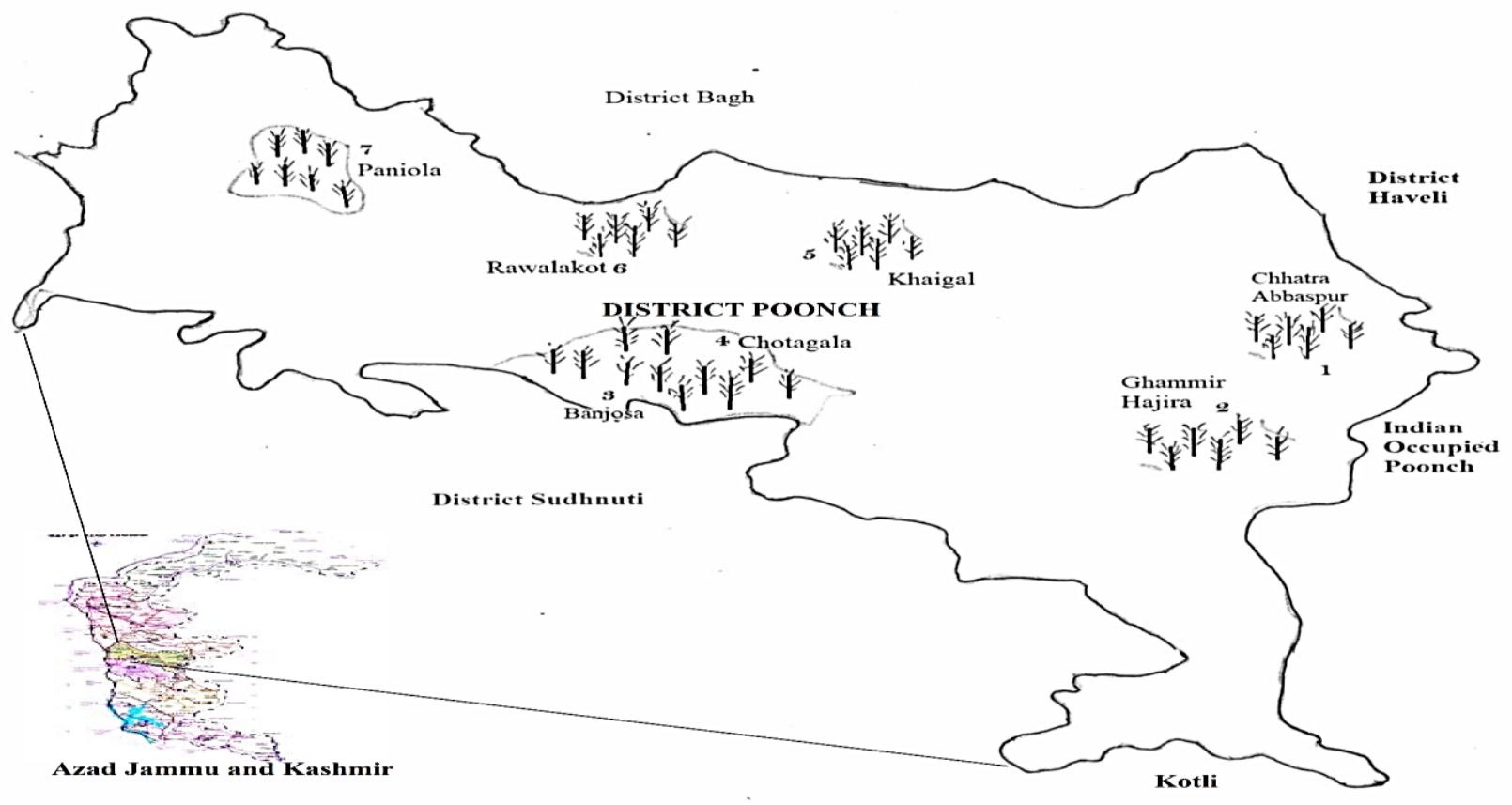

Figure 1. Geographical distribution of mushroom flora from the Study area from district Poonch, Azad Jammu and Kashmir. 
Different mushroom flora growing in the areas especially mixed woodland bogs and marshy places, collected carefully to avoid any physical damage. Deep-rooted specimens were dug out with the help of trowel and spade with shallow based species were manually picked up from the substrate, along with soil, washed carefully and preserved. Wet preservation was done with 5\% formalin solution in jars while specimen was dried in Sunlight, sealed and stored in cool place. Most of the times, collection was done just after the rain to ensure the good result (Gardezi, 2005). Specimens were carried to the laboratory with a lot of care for an elaborate study. Each collection after carrying was given, a specimen number, collector's name, date and location. Some short-lived characters were noted on the spot and photographed. General surface characteristics, odors, color and growth habit of each specimen like depth in the soil, shape and tenderness were enlisted along with habitat and substrates where the mushrooms were grown. Specimens grown on branches, trunks and logs were collected by scratching the substratum with a sharp knife; very often complete portion was removed to ensure not to damage the specimen. The photographs were made by digital camera and portable Olympus zoom camera measurements were made according to Hawksworth et al. (1995) and Læssøe and Lincoff (1999).

Identification: Mushrooms were identified up to the species level with help of taxonomic literature (Singer, 1986) Slides were made to observe and identify basidia and basidiospore, and measurements were taken using ocular lens under compound microscope and comparison and identification of fungi, depending on their taxonomic keys are as follows; Miles and Chang (2004), Christensen (1981), Hall et al. (2003) and Læssøe and Lincoff (1999). Size and shape of spores under the microscope is an important clue in identification of mushroom species. Spore printing technique was used for determination of spore color, size and shape. Cutting of pileus with sterilized fresh blade from the stripe of fresh specimen, placed the pileus on smooth white paper and covered with a glass for few hours and if necessary overnight, in the lab. Process yielded and drops enough number of spores to study under microscope. Glass and pileus were carefully removed and spores were examined for color, size and shape.

\section{RESULTS AND DISCUSSION}

The data illustrated the distribution and occurrence of wild mushrooms which were found in District Poonch of
Azad Jammu and Kashmir. A total of 17 species belong to 14 genera were identified in Poonch region from various locations of the district (Table 1). Mushroom flora distribution is presented in (Figure 1) along with the characters and habitat. The most frequently occurring and identified species were Agaricus arvensi, Amanita vaginata, Amanita fulva, Cantharellus cinereus, Coprinus comatus, Coprinus domesticus, Coprinus micaceus, Cycoperdon perlatum, Daedalea quercina, Helvella crispa, Lepista nuda, Lactarius turpis, Marasmius alliaceus, Panaeolus campanulatus, Pleurotus ostreatus, Trametes versicolor, and Tricholoma ustaloides (Table 1; Figure 1, 2). Nine species were edible Agaricus arvensi, Amanita fulva, Hygrophorus melizeus, Coprinus comatus, Coprinus micaceus, Marasmius alliaceus, Lepista nuda, Helvella crispa and Pleurotus ostreatus. Eight species are poisonous Tricholoma ustaloides, Trametes versicolor, Amanita vaginata, Cantharellus cinereus, Coprinus domesticus, Cycoperdon perlatum, Lactarius turpis and Panaeolus campanulatus. Assawah (1991) reported Agrocybe spp., Hebeloma spp., Lepista spp. and Tricholoma spp. Also El-Souod and Bedaiwy (2000) reprted thirteen species of mushrooms belonging to ten genera, these genera were Agrocybe, Armillaria, Coprinus, Drosella, Hebeloma, Hygrophorus, Lepiota, Leptonia, Panaeolus and Tricholoma.

García et al. (1998) and in Poland Falandysz et al. (1994), identified Coprinus campatus while in USA. Richards (1997) reported Tricholoma spp. A total of 20 species belong to 13 genera of woody and fleshy species of basidiomycetes were identified. Abou-Zeid and Altalhi (2006) hunted Fourteen species of mushrooms belonging to nine genera, identified from seven localities in Al-Taif Saudi Arabia includes: Agaricus arvensi, Agaricus bisporus, Agaricus augustus, Lepiota procera, Lepiota rhacodes, Lepiota cristata, Pleurotus ostreatus, Pleurotus cornucopiae, Coprinus comatus, Agrocybe cylindracea, Podaxis pistillaris, Inocybe splendens, Phaeolepiota aurea and Boletus edulis (Figure 2).

All the 17 collected species were observed morphologically and phenotypic parameter noted in fresh form. The fruiting structures like cap, stalk, gills, volva and annulus were observed as present/absent during collection. The shape and color of fruit bodies was also recorded. The edibility test of collected edible mushrooms was also determined by obtaining information from local and tribal's consuming the same. 
Plant Protection, 02 (01) 2018. 01-06
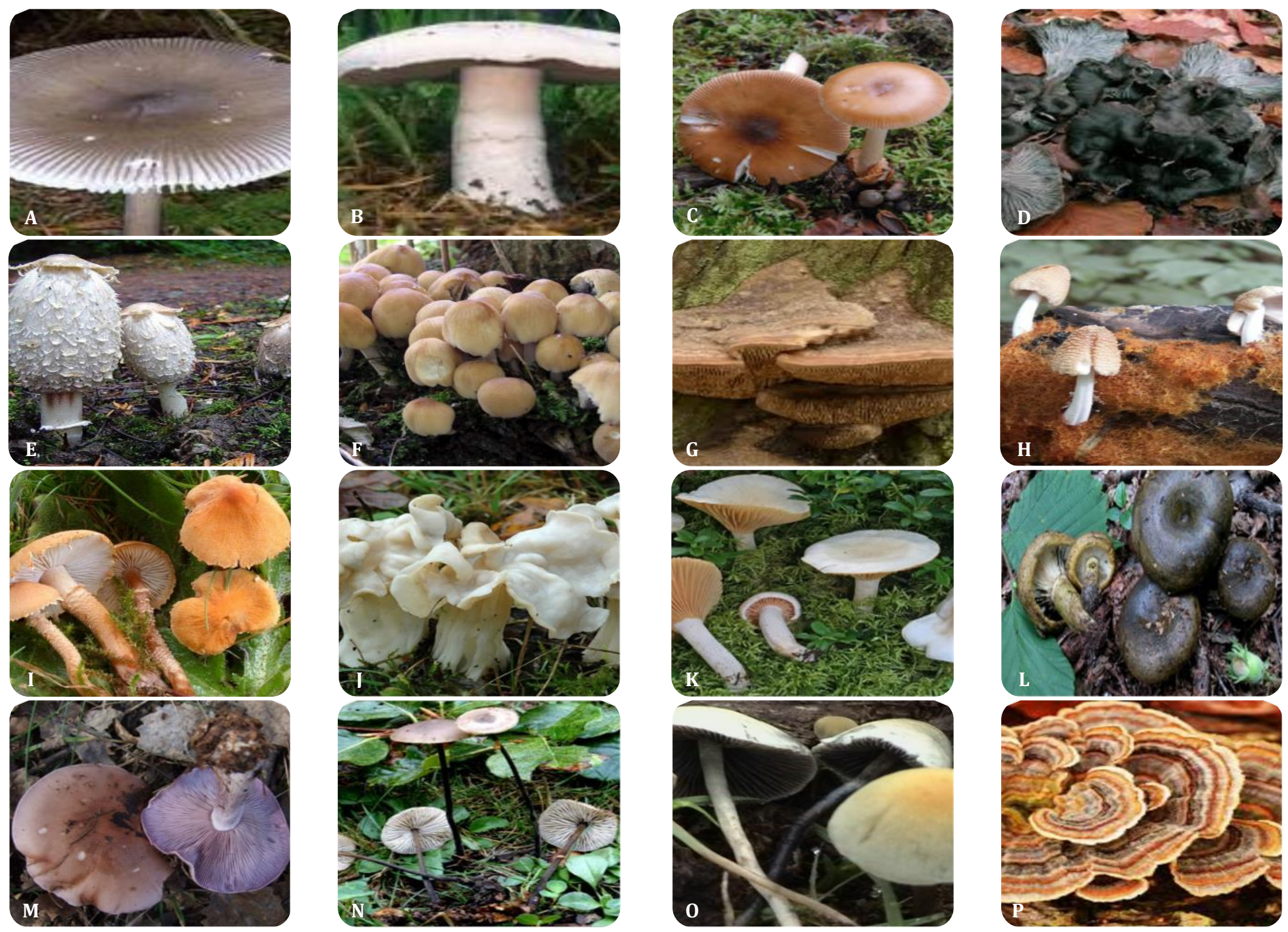

Figure 2. A, Agaricus arvensi, B Amanita vaginata; C Amanita fulva; D Cantharellus cinereus; $\mathbf{E}$ Coprinus comatus; $\mathbf{F}$ Coprinus micaceus; $\mathbf{G}$ Daedalea quercina; H Coprinus domesticus; I Cycoperdon perlatum; J Helvella crispa; $\mathbf{K}$ Hygrophorus melizeus; L Lactarius turpis; $\mathbf{M}$ Lepista nuda; $\mathbf{N}$ Marasmius alliaceus; O Panaeolus campanulatus; $\mathbf{P}$ Trametes versicolor 
Table 1. Detail features of the mushrooms collected from various locations of District Poonch, Azad Jammu and Kashmir.

\begin{tabular}{|c|c|c|c|c|c|}
\hline Location & Species & Spore Color & Spore size $(\mu \mathrm{m})$ & Habitat & Edibility \\
\hline $\begin{array}{l}\text { Chhatra } \\
\text { Abbaspur }\end{array}$ & Amanita fulva & White & $9-11$ & $\begin{array}{l}\text { Mixed woodland solitary to scattered commonly } \\
\text { found }\end{array}$ & Edible \\
\hline \multirow{2}{*}{$\begin{array}{l}\text { Ghammir } \\
\text { Hajira }\end{array}$} & Tricholoma ustaloides & Black & $6-7 \times 4-5$ & Common in broad leaved woods. & Not edible \\
\hline & Trametes versicolor & Black & $4.5-8 \times 1.5-3$ & $\begin{array}{l}\text { On dead and living wood and trunks, both coniferous } \\
\text { and broad-leaved trees, very commonly found }\end{array}$ & Not edible \\
\hline \multirow{4}{*}{ Banjosa } & Agaricus arvensi & White & $7-8 \times 4.5-5$ & $\begin{array}{l}\text { Among grass in pasture or thickest often in rings, } \\
\text { frequent. }\end{array}$ & Edible \\
\hline & Amanita vaginata & White & $9-12$ & $\begin{array}{l}\text { In deciduous wood, or on heaths, solitary to scattered } \\
\text { in the soil. }\end{array}$ & Not edible \\
\hline & Cantharellus cinereus & White & $11-9$ & In broad leaved woods. & Not edible \\
\hline & Hygrophorus melizeus & White & $8-11 \times 5-6$ & In grass usually beneath birch. & Edible \\
\hline \multirow[t]{5}{*}{ Chotagala } & Coprinus comatus & White & $10-13 \times 6.5-8$ & In grass & Edible \\
\hline & Coprinus micaceus & White & $7-10 \times 4.5-6$ & Tufted broad leaved stumps rotting woods. & Edible \\
\hline & Coprinus domesticus & White & $7.5-10 \times 4-5$ & $\begin{array}{l}\text { On dead wood of broad-leaved trees, scattered or } \\
\text { grouped, uncommon }\end{array}$ & Not edible \\
\hline & Cycoperdon perlatum & Black & $4.50-7.5 \times 3-3.5$ & In coniferous woods and on health land. & Edible \\
\hline & Lactarius turpis & Pale cream & $.8-11 \times 7-9$ & Always, with birch. & Not edible \\
\hline Khaigala & Marasmius alliaceus & $\begin{array}{l}\text { Faintly } \\
\text { pinkish }\end{array}$ & $8-7 \times 6-7$ & $\begin{array}{l}\text { Wood or dead leaves rarely found beneath other } \\
\text { broad leaved trees }\end{array}$ & Edible \\
\hline \multirow[t]{3}{*}{ Rawalakot } & Lepista nuda & $\begin{array}{l}\text { Faintly } \\
\text { pinkish }\end{array}$ & $8-12 \times 6-8$ & $\begin{array}{l}\text { In humus rich ground in broad leaved and coniferous } \\
\text { wood. }\end{array}$ & Edible \\
\hline & Helvella crispa & White & $16-21 \times 10-14$ & $\begin{array}{l}\text { On fine sandy ground epically in open wood land } \\
\text { parts. }\end{array}$ & Edible \\
\hline & Panaeolus campanulatus & Black & $4-6 \times 3-5$ & Isolated in small groups in fields and grass land. & Not edible \\
\hline Paniola & Pleurotus osteratus & White & $7.5-11 \times 3-4$ & $\begin{array}{l}\text { Often in large clusters on stumps and fallen or } \\
\text { standing trunks, usually of deciduous trees, especially } \\
\text { beech, commonly found. }\end{array}$ & Edible \\
\hline
\end{tabular}

Details of morphological features estimated by using Gardezi (2000) and Nielsen (2017).

This information noted as fruiting stage and edible part of mushroom at the time of consumption and as well as their taste flavor and chewing nature. Nine mushroom out of
17 that Agaricus arvensi, Amanita fulva, Hygrophorus melizeus, Coprinus comatus, Coprinus micaceus, Marasmius alliaceus, Lepista nuda, Helvella crispa and Pleurotus ostreatus have excellent edibility. The flavor of collected edible mushroom were having different flavor such as cheese, vegetable, fish, chicken. 


\section{REFERENCES}

Abou-Zeid, A., Altalhi, A.E., 2006. Survey of some mushrooms in Al-Taif governorate of Saudi Arabia. World Journal of Agricultural Sciences 2, 1-5.

Assawah, W.S., 1991. Biochemical studies on some mushrooms in Egypt. Faculty of Science, Tanta University, Tanta, Egypt.

Boa, E.R., 2004. Wild edible fungi: A global overview of their use and importance to people. Food and Agriculture Organization, Rome, Italy.

Christensen, C.M., 1970. Common edible mushrooms. Lund Press, Minneapolis, USA.

Christensen, C.M., 1981. Edible Mushrooms, 2nd ed. CSR Press, United States of America.

Courtenay, B., Burdsall, H.H., 1982. A Field Guide to Mushrooms and their Relatives. Van Nostrand Reinhold Company.

El-Souod, A., Bedaiwy, M., 2000. Survey of mushrooms and polypores fungi in Delta region of Egypt, 1st International Conference Biological Sciences, Faculty of Sciences, Tanta University, pp. 525-545.

Falandysz, J., Bona, H., Danisiewicz, D., 1994. Silver content of wild-grown mushrooms from Northern Poland. Zeitschrift-fur-lebensmittel Untersuchu-ng and Forschung 199, 222-224.

García, M.A., Alonso, J., Fernández, M.I., Melgar, M.J., 1998. Lead content in edible wild mushrooms in morthwest Spain as indicator of environmental contamination. Archives of Environmental Contamination and Toxicology 34, 330-335.

Gardezi, S.R.A., 2000. Taxonomy, morphology and biochemical analysis of mushrooms of Azad Jammu and Kashmir. Quaid-i-Azam University, Islamabad, Pakistan.

Gardezi, S.R.A., 2005. Notes on scleroderma, puff balls and geastrum of Azad Jammu and Kashmir, Pakistan. Archives Of Phytopathology And Plant Protection 38, 113-122.

Hall, I.R., Buchanan, P.K., Cole, A.L., Yun, W., Stephenson, S., 2003. Edible and poisonous mushrooms of the world. Timber Press Portland.

Hawksworth, D.L., Kirk, P.M., Sutton, B.C., Pegler, D.N., 1995. Ainsworth and Bisby's Dictionary of the Fungi. CAB International, WallingFord, UK.

Hobbs, C., 1995. Mushrooms, Medicinal: An Exploration of Tradition, Healing and Culture, 2nd ed. Botanica Press, Santa Cruz, CA, USA.

Kibby, G., 1979. Mushrooms and Toadstools. A Field Guide. Oxford University Press., Walton Street, Oxford.

Læssøe, T., Lincoff, G., 1999. Mushrooms. Eyewitness Handbook. Kyodo Printing Company, Singapore.

Miles, P.G., Chang, S.-T., 2004. Mushrooms: Cultivation, nutritional value, medicinal effect, and environmental impact, 2nd ed. CRC press, Boca Raton.

Nielsen, S.S., 2017. Food Analysis Laboratory Manual. Springer.

Pandey, G., Singh, B.K., 1978. Indian mushroom. Sciences 1, 383-388.

Richards, R.T., 1997. What the natives know: Wild mushrooms and forest health. Journal of Forestry 95, 4-10.

Rojas, C., Mansur, E., 1995. Ecuador: Informaciones generales sobre productos non madereros en Ecuador, Memoria, consulta de expertos sobre productos forestales no madereros para America Latina y el Caribe, pp. 208-223.

Singer, Q., 1986. The Agaricale on modern taxonomy, 4th ed. Singh Publication, Dehrndum, India. 